Images in...

\title{
Tooth agenesis
}

\author{
Upendra Jain, ${ }^{1}$ Amitabh Kallury, ${ }^{2}$ Gagan Thakur ${ }^{3}$
}

${ }^{1}$ Department of Orthodontics, People's College of Dental Sciences and Research Centre, Bhopal, Madhya Pradesh, India;

${ }^{2}$ Department of Orthodontics, People's Dental Academy, Bhopal, Madhya Pradesh, India;

${ }^{3}$ Department of Oral and Maxillofacial Surgery, People's College of Dental Sciences and Research Centre, Bhopal, Madhya Pradesh, India

Correspondence toDr Gagan Thakur, drgagan05@yahoo.com

\section{DESCRIPTION}

A 27-year-old male reported with the chief complaint of forwardly placed front teeth and unpleasant smile. Medical history was not significant. Extra-oral examination revealed mesoprosopic face, reduced lower anterior facial height, deep mentolabial sulcus and lip trap (figure 1). On intra oral examination there was Angle's class I molar relationship with severely proclined maxillary central incisors. All the teeth mesial to first molars except maxillary central incisors and right mandibular first premolar were absent. The deciduous maxillary right and left canines, right maxillary first and left maxillary second deciduous molars were still retained (figures 2 and 3). Queries revealed that missing teeth were absent since childhood and his sister had similar dental pattern. The prevalence of congenitally missing teeth varies greatly according to geographic location and

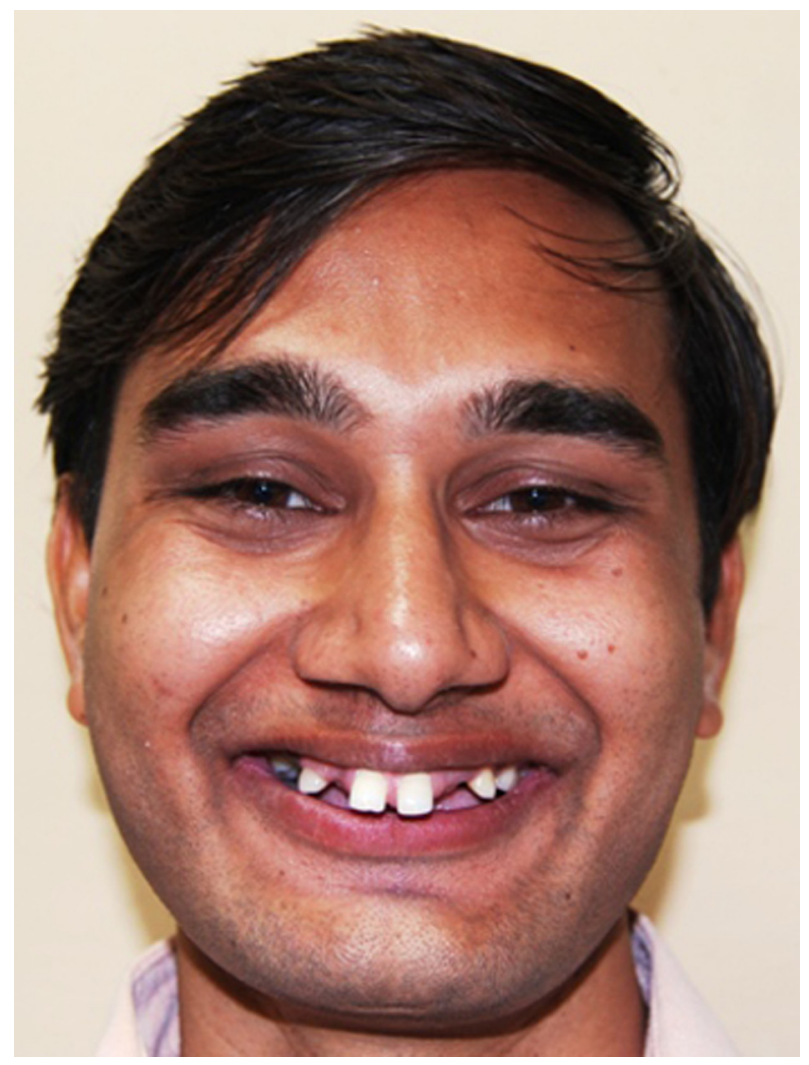

Figure 1 Extra-oral view. race, ranging from $1.6 \%$ to $9.6 \% .{ }^{1}$ Permanent teeth are more frequently affected than deciduous teeth. The mandibular second premolar is the most frequently reported missing tooth, followed by the permanent maxillary lateral incisor and maxillary second premolar. ${ }^{2}$ This condition can present as stand alone problem or may be associated with syndromes. Both genetic and environmental factors have been implicated in the aetiology. ${ }^{3}$

Competing interests None.

Patient consent Obtained.

\section{REFERENCES}

1. Clayton JM. Congenital dental anomalies occurring in 3,557 children. J Dent Child 1956;23:206-8.

2. Symons AL, Stritzel F, Stamation J. Anomalies associated with hypodontia of the permanent lateral incisor and second premolar. J Clin Pediatr Dent 1993;17:109-11.

3. Kokich VG, Kokich VO. Congenitally missing mandibular second premolars: clinical options. Am J Orthod Dentofacial Orthop 2006;130:437-44.

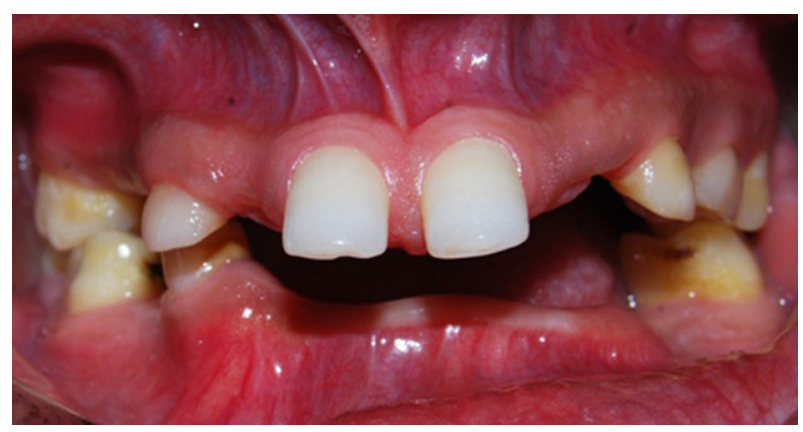

Figure 2 Intra oral view.

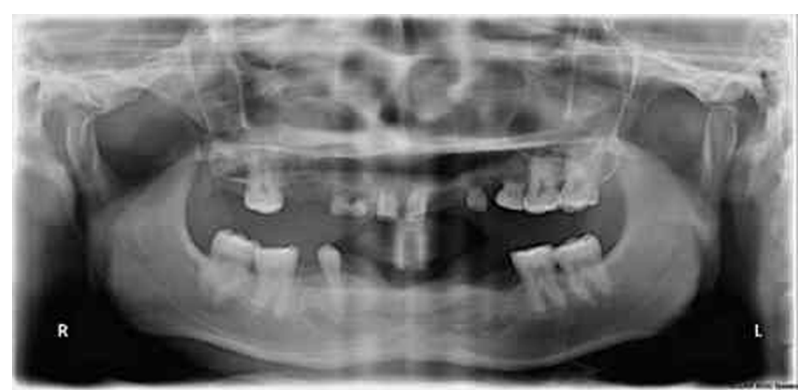

Figure 3 Orthopantomograph. 


\section{BMJ Case Reports}

This pdf has been created automatically from the final edited text and images.

Copyright 2011 BMJ Publishing Group. All rights reserved. For permission to reuse any of this content visit http://group.bmj.com/group/rights-licensing/permissions.

BMJ Case Report Fellows may re-use this article for personal use and teaching without any further permission.

Please cite this article as follows (you will need to access the article online to obtain the date of publication).

Jain U, Kallury A, Thakur G. Tooth agenesis. BMJ Case Reports 2011;10.1136/bcr.08.2011.4681, date of publication

Become a Fellow of BMJ Case Reports today and you can:

- Submit as many cases as you like

- Enjoy fast sympathetic peer review and rapid publication of accepted articles

- Access all the published articles

- Re-use any of the published material for personal use and teaching without further permission

For information on Institutional Fellowships contact consortiasales@bmjgroup.com

Visit casereports.bmj.com for more articles like this and to become a Fellow 